\title{
PENGARUH pH LENDIR MUKOSA VAGINA SAAT BIRAHI TERHADAP PERSENTASE KEBUNTINGAN (Conception Rate) PADA SAPI PERAH DI KUD TANI WILIS KABUPATEN TULUNGAGUNG DAN KSU TUNAS SETIA BARU KABUPATEN PASURUAN
}

\section{THE EFFECT OF MUCOS ACIDITY OF VAGINA MUCOUS WHEN ESTRUS AND CONCEPTION RATE (CR) ON DAIRY CATTLE IN KUD TANI WILIS TULUNGAGUNG DISTRICT AND KSU TUNAS SETIA BARU PASURUAN DISTRICT}

\author{
Andaru Rizki ${ }^{1)}$, *Pudji Srianto ${ }^{2)}$, Endang Suprihati ${ }^{3)}$, Trilas Sardjito ${ }^{4)}$, \\ Ismudiono ${ }^{5)}$, Mohammad Anam Al Arif ${ }^{(6)}$ \\ ${ }^{1)}$ Mahasiswa, ${ }^{2,4,5)}$ Departemen Reproduksi Veteriner, ${ }^{3)}$ Departemen Parasitologi Veteriner, \\ ${ }^{6}$ Departemen Peternakan Veteriner \\ Faculty of Veterinary Medicine, Universitas Airlangga \\ *Corresponding author: email: pudjisrianto@yahoo.com; rizkiandaru@gmail.com
}

\begin{abstract}
The purpose of this research is to determine the effect of mucos acidity of vaginal mucous when estrus towards conception rate at KUD Tani Wilis Tulungagung District and KSU Tunas Setia Baru Pasuruan District. Measured samples were taken from 30 dairy cattles in each KUD. Mucos acidity of vaginal mucous were obtained by using a digital acidity meter before insemination was done on dairy cattle. After measuring the acidity from mucosal vagina mucous, artificial insemination has done on estrus dairy cattle. On the 60th day after insemination, rectal palpation was done to check the conception rate. Research result from 30 dairy cattle on each KUD showed that mucos acidity of vaginal mucous has signifficant effect towards conception rate. Mucos acidity of vaginal mucous range 6.5-8.5 with the highest range of conception rate in KSU Tunas Setia Baru Pasuruan District 7.5-7.7 and in KUD Tani Wilis Tulungagung District with the highest range of conception range 7.2-7.4 and 7.5-7.7.

Keywords: Dairy cows, Mucous acidity of vaginal mucous, Conception Rate (CR)
\end{abstract}

\section{Pendahuluan}

Sebagian besar masyarakat di Indonesia terutama di pedesaan mengenal berbagai macam peternakan, salah satunya adalah ternak sapi perah. Di Indonesia umumnya sapi perah yang dipelihara ialah jenis $\mathrm{FH}$ (Friesian Holstein) . Sapi perah adalah penghasil susu dan daging dalam pemenuhan kebutuhan protein, namun populasi sapi perah dalam negeri yang masih rendah menyebabkan produksi susu hanya mencakupi $30 \%$ dari permintaan (Farid dan Sukesi, 2011).

Sebuah usaha peternakan sapi perah memerlukan anggaran kebutuhan pakan mencapai $70 \%$ dari seluruh biaya produksi. Fungsi pakan bagi ternak utamanya adalah sebagai pemenuhan hidup pokok, partumbuhan, reproduksi, dan produksi susu. Produksi susu yang berkualitas tinggi di- hasilkan oleh peternakan yang mempunyai pengelolaan dan manajemen pakan yang baik, disamping itu juga tergantung dari genetik dan stadium laktasi sapi perah (Sidik, 2004). Dalam penelitian Sori Basya (1993) pemberian rumput gajah pada sapi perah laktasi diperoleh data bahwa, untuk mencapai produksi susu yang lebih tinggi, dibutuhkan pemberian pakan yang mengandung protein kasar sekitar 21-22\%, Kebutuhan protein tersebut sangat sulit dicapai apabila di suplai dari hijauan saja tanpa di tambahkan konsentrat karena kandungan protein yang terdapat dalam hijauan Khususnya pada rumput gajah terdapat sekitar $7 \%$.

Teknologi Inseminasi buatan (IB) adalah salah satu teknologi reproduksi yang mampu dan telah berhasil meningkatkan perbaikan genetik ternak, Salah satu para- 
meter keberhasilan IB adalah dengan Conception Rate dan rata-ratanya pada sapi berkisar 60\% (Hariadi dkk., 2011). Conception rate akan mengalami penurunan apabila tidak memenuhi faktor - faktor yang berpengaruh dalam keberhasilan IB yaitu, pemilihan sapi perah aseptor, usaha pemberantasan kemajiran, kemampuan peternak mengetahui birahi sapi, keterampilan inseminator, kualitas dan kuantitas semen (Susilowati dkk., 2010).

Derajat keasaman $(\mathrm{pH})$ merupakan parameter penting dari lendir serviks dalam proses transfer sperma ke dalam saluran reproduksi betina, $\mathrm{pH}$ mempengaruhi kualitas daya hidup sperma di dalam serviks (Tsiligianni et al.,2011). Lokasi yang di pilih pada penelitian ini adalah KSU Tunas Setia Baru kabupaten Pasuruan dan KUD Tani wilis kabupaten Tulungagung kedua KUD .

Mengingat pentingnya penentu produktivitas sapi perah maka perlu dilakukannya evaluasi reproduksi serta akurasi deteksi birahi yang tepat hasil IB sapi perah yang dipelihara. Penelitian ini bertujuan untuk mengetahui pengaruh $\mathrm{pH}$ lendir mukosa vagina terhadap presentase Conception Rate (CR) pada sapi perah setelah dilakukannya inseminasi buatan (IB) di KUD Tani Wilis Kabupaten Tulungagung dan KSU Tunas Setia Baru Kabupaten Pasuruan.

\section{Materi dan Metode Penelitian \\ Tempat dan Waktu Penelitian}

Penelitian ini dilaksanakan di Koperasi Serba Usaha Tunas Setia Baru Kecamatan Tutur Kabupaten Pasuruan dan Koperasi Unit Desa (KUD) Tani Wilis, Kecamatan Sendang, Kabupaten Tulungagung. Waktu penelitian ini dilaksanakan pada bulan Januari hingga Maret 2018.

\section{Alat dan Bahan Penelitian}

Alat penelitian yang digunakan adalah larutan PBS, kapas, pH-98103 digital untuk mengukur nilai $\mathrm{pH}$ mukosa vagina. Bahan untuk penelitian ini adalah masing masing 30 sapi perah betina birahi pada wilayah KSU Tunas Setia Baru dan KUD Tani Wilis, larutan pbs dan kapas digunakan untuk menjaga alat $\mathrm{pH}$ meter agar tetap steril setelah digunakan.

\section{Metode Penelitian. \\ Pengukuran dengan Alat pH - 98103 Di- gital}

Pendataan penelitian ini merupakan eksploratif lapangan. Dengan memasukkan alat $\mathrm{pH}$ meter digital pada vagina sapi yang birahi. Kemudian pencatatan data $\mathrm{pH}$ mukosa vagina sapi perah birahi tepat sebelum dilakukan Inseminasi Buatan (IB).

\section{Pelaksanaan Inseminasi Buatan (IB)}

Inseminasi Buatan dilakukan terlebih dahulu selanjutnya dilakukan pengukuran $\mathrm{pH}$ menggunakan $\mathrm{pH}$ meter digital pada mukosa vagina.

\section{Pendataan Conception Rate (CR)}

Pendataan conception rate dilakukan melalui palpasi rektal oleh inseminator pada hari ke-60 setelah dilakukannya inseminasi buatan pada sapi perah yang menunjukan kebuntingan.

$$
\text { Conception Rate }(\%)=
$$

$\frac{\text { Jumlah induk yang bunting pada IB pertama }}{\text { Jumlah seluruh induk yang di IB }} \times 100 \%$

\begin{abstract}
Analisis Data
Analisis data dilakukan dengan mengumpulkan data primer yaitu $\mathrm{pH}$ mukosa vagina saat birahi pada sapi perah, Conception Rate (CR) pada hari ke 60-75 hari. Data di proses menggunakan uji $\mathrm{T}$ dan uji ChiSquare dengan aplikasi SPSS. Uji T dilakukan dengan mengujikan $\mathrm{pH}$ mukosa vagina saat birahi pada masing-masing KUD 30 sapi, uji Chi-square untuk mengetahui $\mathrm{pH}$ lendir mukosa vagina terhadap jumlah angka kebuntingan dari 2 KUD yaitu Koperasi Serba Usaha (KSU) Tunas Setia Baru Kecamatan Tutur Kabupaten Pasuruan dan KUD Tani Wilis, Kecamatan Sendang, Kabupaten Tulungagung.
\end{abstract}

\section{Hasil dan Pembahasan}

Pada penelitian ini dari 30 ekor sapi yang telah IB dari masing-masing KUD menunjukkan pada KUD Tani Wilis Kabupaten Tulungagung di dapatkan 25 sapi yang bunting dan 5 ekor sapi yang tidak bunting dengan range $\mathrm{pH}$ dan persentase kebuntingan yang paling tinggi yaitu 7,27,4 dan 7,5-7,7 sedangkan 7 ekor sapi yang tidak bunting dan 23 sapi yang bunting di KSU Tunas Setia Baru di dapatkan range 
$\mathrm{pH}$ dengan persentase kebuntingan yang tinggi yaitu pada $\mathrm{pH}$ 7,5-7,7.

Berdasarkan hasil uji Chi-square $\mathrm{pH}$ lendir mukosa vagina terhadap persentase kebuntingan di KUD Tani Wilis Kabupaten Tulungagung dan KSU Tunas Setia Baru Kabupaten Pasuruan, keduanya mendapatkan hasil bahwa $\mathrm{pH}$ lendir mukosa vagina berpengaruh secara signifikan terhadap persentase kebuntingan $(p<0,05)$. Hasil uji test tersebut dapat dilihat pada tabel 1 dan 2 .

Kemudian untuk uji $\mathrm{T}$ test rata-rata $\mathrm{PH}$ lendir Vagina di KUD Tani Wilis Kabupaten Tulungagung dan KSU Tunas Setia Baru Kabupaten Pasuruan menunjukkan bahwa $\mathrm{pH}$ lendir mukosa vagina di KUD Tani Wilis Kabupaten Tulungagung dan KSU Tunas Setia Baru Kabupaten Pasuruan menunjukkan tidak berbeda nyata $(p>0,05)$. Hasil uji $\mathrm{T}$ test tersebut dapat dilihat pada tabel 3.

Untuk hasil uji Chi-square pH lendir Mukosa Vagina Terhadap Jumlah Conception Rate di KUD Tani Wilis Kabupaten Tulungagung dan KSU Tunas Setia Baru Kabupaten Pasuruan dapat disimpulkan bahwa $\mathrm{pH}$ lendir mukosa vagina berpengaruh terhadap angka kebuntingan di KUD Tani Wilis Kabupaten Tulungagung dan KSU Tunas Setia Baru Kabupaten Pasuruan. Hasil uji tersebut dapat dilihat pada tabel 4.

Sedangkan Persentase kebuntingan di KUD Tani Wilis Kabupaten Tulungagung dan KSU Tunas Setia Baru Kabupaten Pasuruan menunjukkan pengukuran $\mathrm{pH}$ lendir mukosa vagina pada sapi perah cenderung basa . Pada penelitian ini dari 30 ekor sapi yang telah IB dari masing-masing KUD menunjukkan pada KUD Tani Wilis Kabupaten Tulungagung di dapatkan 25 sapi yang bunting dan 5 ekor sapi yang tidak bunting dengan range $\mathrm{pH}$ dan persentase kebuntingan yang paling tinggi yaitu 7,27,4 dan 7,5-7,7 sedangkan 7 ekor sapi yang tidak bunting dan 23 sapi yang bunting di KSU Tunas Setia Baru di dapatkan range $\mathrm{pH}$ dengan persentase kebuntingan yang tinggi yaitu pada $\mathrm{pH}$ 7,5-7,7. Hasil ini dapat dilihat pada tabel 5 .

Hal ini di mungkinkan adanya beberapa faktor yang mempengaruhi perbedaan $\mathrm{pH}$ dan pengaruh $\mathrm{pH}$ terhadap angka kebuntingan. Faktor yang mempengaruhi perbedaan $\mathrm{pH}$ lendir mukosa vagina pada sapi perah tersebut dipengaruhi oleh kondisi biofisik dan biokimia dari lendir yang dihasilkan oleh serviks itu sendiri yang dikendalikan oleh hormon yang berperan selama siklus estrus (Prasdini dkk., 2015). Verma et al. (2014) menyatakan bahwa penampilan lendir serviks berubah selama perubahan fase estrus yaitu, transparan pada awal estrus, yang secara bertahap berubah menjadi keruh pada pertengahan estrus dan bening mengkilap pada akhir estrus.

Semakin tinggi hormon estrogen dalam darah saat estrus maka volume lendir serviks akan semakin banyak dengan $\mathrm{pH}$ yang semakin basa (Suharto, 2003). Sehingga dapat digunakan sebagai acuan untuk keberhasilan Inseminasi Buatan (IB). Dalam fase estrus, hormon FSH dalam darah menurun, sedangkan sekresi LH meningkat guna merangsang terjadinya ovulasi, salah satu faktor yang mempengaruhi produksi lendir serviks adalah hormon estrogen. Bagian mucus terdapat kripta-kripta yang dapat menghasilkan lendir sehingga pada saat ternak tidak mengalami estrus, lendir yang ada pada kripta mengeras dan akan mencair saat hormon estrogen meningkat (Widiyono et al., 2011).

Hormon pengendali siklus birahi yaitu hormon hipofisa anterior dan hormon dari ovaria. Hormon hipofisa anterior yang jelas berperan mengendalikan siklus birahi adalah FSH dan LH, semua hormon tersebut adalah bersifat protein. hormon FSH merangsang pertumbuhan folikel ovarium. FSH dianggap sebagai substansi yang mengawali siklus birahi, karena secara normal aktifitas birahi tidak akan terjadi sebelum folikel bertumbuh dan masak terlihat di dalam ovaria. Pada fase estrus keseimbangan hormon hipofisa bergeser dari FSH ke LH. LH membantu terjadinya ovulasi dan pembentukan corpus luteum.

Salah satu komponen untuk menilai baik tidaknya pelaksanaan IB adalah dengan memeriksa atau mendata (conception rate). Hasil penelitian ini di peroleh persentase conception rate di KUD Tani Wilis Kabupaten Tulungagung yaitu $83 \%$ dan di KSU Tunas Setia Baru Kabupaten Pasuruan adalah conception rate $76,6 \%$. Hasil tersebut di nilai baik karena efisiensi reproduksi pada sapi dikatakan baik apabila nilai Conception Rate dapat mencapai 65-75 \%. Kualitas pakan dan kebutuhan nutrisi juga 
berpengaruh terhadap nilai conception rate, hal ini sesuai dengan pernyataan Nkuna (2008) yang menyebutkan bahwa salah satu faktor yang mempengaruhi angka kebuntingan yaitu nutrisi. Pakan yang hanya berasal dari rumput kering dengan protein yang rendah memiliki kandungan mineral fosfor yang rendah. Kekurangan protein dalam pakan dapat mengakibatkan ternak antara lain an-estrus, silent estrus, birahi yang tidak teratur (Hariadi dkk, 2011). Jumlah kandungan protein dalam kedua KUD tersebut sudah melampaui nilai kandungan yang baik yaitu $21-22 \%$ pada KUD Tani Wilis kadar protein 24,73 dengan konsumsi protein 4,44 kg dan di KSU Tunas Setia Baru dengan Kadar Protein 23,07 dengan konsumsi pakan 5,2 kg, sehingga nilai angka kebuntingan pun tinggi .

Tabel 1. Range pH Lendir Mukosa Vagina terhadap Persentase Kebuntingan di KUD Tani Wilis Kabupaten Tulungagung

\begin{tabular}{ccccc}
\hline $\begin{array}{c}\text { Range pH Lendir } \\
\text { Mukosa Vagina }\end{array}$ & \multicolumn{2}{c}{ Tulungagung } & Total & $\begin{array}{c}\text { Persentase } \\
\text { bunting }\end{array}$ \\
\hline $6,8-7,1$ & 0 & Tidak Bunting & & $0 \%$ \\
$7,2-7,4$ & 14 & 0 & 1 & $100 \%$ \\
$7,5-7,7$ & 9 & 0 & 14 & $100 \%$ \\
$7,8-8,0$ & 2 & 3 & 9 & $40 \%$ \\
$8,1-8,5$ & 0 & 1 & 5 & $0 \%$ \\
\hline
\end{tabular}

Tabel 2. Range pH lendir Mukosa Vagina terhadap Persentase Kebuntingan di KSU Tunas Setia Baru Kabupaten Pasuruan.

\begin{tabular}{ccccc}
\hline $\begin{array}{c}\text { Range } \mathrm{pH} \text { Lendir } \\
\text { Mukosa Vagina }\end{array}$ & Bunting & $\begin{array}{c}\text { Pasuruan } \\
\text { Tidak Bunting }\end{array}$ & Total & Persentase bunting \\
\hline $6,8-7,1$ & 1 & 2 & 3 & $33,3 \%$ \\
$7,2-7,4$ & 9 & 1 & 10 & $90 \%$ \\
$7,5-7,7$ & 7 & 0 & 7 & $100 \%$ \\
$7,8-8,0$ & 6 & 2 & 8 & $75 \%$ \\
$8,1-8,5$ & 0 & 2 & 2 & $0 \%$ \\
\hline
\end{tabular}

Tabel 3. Rata-rata pH Lendir Mukosa Vagina di KUD Tani Wilis Kabupaten Tulungagung dan KSU Tunas Setia Baru Kabupaten Pasuruan.

\begin{tabular}{ccc}
\hline No & Daerah & Rata-rata $\mathrm{pH}$ lendir mukosa \\
\hline 1 & Tulungagung & 7,4967 \\
2 & Pasuruan & 7,5467 \\
\hline
\end{tabular}

Tabel 4. Hasil uji Chi-square pH lendir Mukosa Vagina Terhadap Jumlah Conception Rate di KUD Tani Wilis Kabupaten Tulungagung dan KSU Tunas Setia Baru Kabupaten Pasuruan.

\begin{tabular}{cccc}
\hline Daerah & $\begin{array}{c}\text { Rata-rata } \mathrm{pH} \text { lendir } \\
\text { mukosa vagina }\end{array}$ & Bunting & Tidak Bunting \\
\hline Tulungagung & 7,4967 & 25 & 5 \\
Pasuruan & 7,5467 & 23 & 7 \\
\hline
\end{tabular}

Tabel 5. Persentase kebuntingan di KUD Tani Wilis Kabupaten Tulungagung dan KSU Tunas Setia Baru Kabupaten Pasuruan

\begin{tabular}{cccc}
\hline Tempat & Bunting & Tidak Bunting & Angka kebuntingan \\
\hline Tulungagung & 25 & 5 & $83,3 \%$ \\
Pasuruan & 23 & 7 & $76,6 \%$. \\
\hline
\end{tabular}




\section{Kesimpulan}

Berdasarkan hasil penelitian ini dapat disimpulkan bahwa :

1. Tidak terdapat perbedaan $\mathrm{pH}$ lendir mukosa vagina saat inseminasi buatan di KUD Tani Wilis Kabupaten Tulungagung dengan rata-rata $\mathrm{pH} \quad 7,4967$ dengan range paling tinggi ang-ka kebuntingnya pada $\mathrm{pH}$ 7,2-7,4 dan 7,57,7 dan di KSU Tunas Setia Baru Kabupaten Pasuruan 7,5467 dengan range paling tinggi angka kebuntingan pada $\mathrm{pH}$ 7,5-7,7.

2. Persentase kebuntingan di KUD Tani wilis Kabupaten Tulungagung yaitu 83,3\% dan KSU Tunas Setia Baru Kabupaten Pasuruan dengan persentase con-ception rate $76,6 \%$.

\section{Daftar Pustaka}

Basya S. 1993. Perimbangan Optimal Hijau-an dan Konsentrat dalam Ransum Sapi Perah Laktasi. Balai Penelitian Ternak, Bogor. 41.

Farid, M. dan N. Sukesi. 2011. Pengembangan Susu Segar Dalam Negeri Untuk Pemenuhan Kebutuhan Susu Nasional. Buletin Ilmiah Litbang Perdagangan.5(2): 1- 26.

Hariadi, S.,S. Hardjoranjoto, Wurlina, H. A. Hermadi, B.Utomo, Rimayanti, I. N. Triana dan H, Ratnani. 2011. Buku Ajar Ilmu Kemajiran pada Ternak. Cetakan Pertama. Airlangga University Press. Surabaya. 1-91.

Prasdani, W. A., S. Rahayu, dan M.S.Djati. 2015. Level of Esterogen and Cervical Mucous $\mathrm{pH}$ as Indicator of Estrus After Calving Towards The Provision of Selenium-vitamin $\mathrm{E}^{\mathrm{TM}}$ on Diary Cow Frisien Holstein (FH). International Jour-nal of ChemTech Research. 7(1) : 190-195.
Sidik, R. 2004. Komoditas dan Bangsa Ternak Perah. Sub Bagian Produksi Ternak. Fakultas Kedokteran Hewan. Universitas Airlangga. Surabaya.

Suharto, K 2003. Penampilan Potensi Reproduksi Sapi Perah Friesian Holstain Akibat Pemberian Kualitas Ransum Berbeda dan Infusi Larutan Iodium Povidon 1\% Intra Uterin Fakultas peternakan UN-DIP. Semarang.

Susilawati, T. 2011. Tingkat Keberhasilan Inseminasi Buatan dengan Kualitas dan Deposisi Semen yang Berbeda pada Sapi Peranakan Ongole. J. Ternak Tropika. 12(2): 15-24.

Tsiligianni, T ., Amiridis, GS., Dovolou. E., Menegatos, I., Chadio, S., Rizos, D., and Gutierrez-Adan, A. 2011. Association between physical properties of cervical mucus and ovulation rate in superovulated cows. The Canadian Journal of Veterinary Research. 75: 248-253.

Verma, K. K., S. Prasad., A. Kumaresan, T. K. Mohanty, S. S. Layek, T. K. Patbandha and S. Chand. 2014. Characterization of Physico Chemical Properties of Cervical Mucus in Relation to Parity and Conception Rate in Murrah Buffaloes. Veterinary World. 7(7): 467-471. 